Розглянуто фізико-хімічні процеси, що протікають при одержанні ангобних покриттів для будівельної кераміки з декоративним ефектом «під давнину», запропоновано склад иихти, технологію виготовлення та нанесення покриттів на керамічний виріб. Покриття мають темний коричнево-бузъковий колір з об'ємним ефектом світлої «мінливості». Ангоби можуть бути використані при декоруванні лицьової керамічної цегли однократного випалу з витримкою при максимальній темnepamypi $1070{ }^{\circ} \mathrm{C}$.

Встановлено, що для забезпечення градієнтного об'ємного декоративного ефекту до складу ангобної иихти рекомендується вводити мікросфери золи-винесення ТЕС у кількості 3-5\%, а для насиченого коричнево-бузъкового забарвлення - до 60 мас.\% марганцевої руди. Для забезпечення необхідних реологічних показників ангобного илікеру та його високої адгезійної здатності, тонкість помелу компонентів иихти має становити не більше 1 \% за залишком на ситі № 0063. При цьому вологість шлікеру становить $45 \%$, текуиість 18 c.

Встановлено механізми протікання усадочних прочесів ангобних покриттів та керамічної основи при різних способах нанесення ангобного шлікеру на виріб. Для зменшення різниці усадок покриття та кераміки рекомендується нанесення ангобного шлікеру розробленого складу на висушений керамічний напівфабрикат.

Після випалу при $1070{ }^{\circ} \mathrm{C}$ вироби мають високу якість з показником водопоглинання покриття 5,2-5,4\% та твердістю за шкалою Моосу $\sim 5$.

Отримані дані можуть бути застосовані при моделюванні процесів ангобування виробів та розробиі складів ангобних покриттів. Практична цінність результатів полягає $y$ створенні нового виду декорованої будівельної продукиї, що дозоляє збільшити ринок ї̈ збуту та підвищити конкурентну спроможність

Ключові слова: керамічна лицьова цегла, ангоб, декоративне покриття, водопоглинання, марганцева руда, випал будівельної кераміки
UDC 666.3.052:666.297

DOI: $10.15587 / 1729-4061.2019 .180367$

\title{
DEVELOPMENT OF THE TECHNOLOGY FOR OBTAINING ENGOBED CONSTRUCTION ARTICLES WITH THE "ANTIQUITY" EFFECT
}

\author{
O. K h o m e n k o \\ $\mathrm{PhD}$, Associate Professor* \\ E-mail: elenahtks@ukr.net \\ B. Da t se n ko
}

PhD, Associate Professor, Senior Researcher, Head of Department

Department of Product Development and Technology

PJSC SBK

Mykilsko-Slobidska str., 2B, Kyiv, Ukraine, 02002

E-mail: b.datsenko@sbk.com.ua

N. S ribniak

$\mathrm{PhD}$, Associate Professor

Department of Building Structures**

E-mail: nataliya.sribnyak.17@gmail.com

O. Z a i c h u k

Doctor of Technical Sciences, Associate Professor* E-mail: zaychuk_av@ukr.net

M. Nahorn y i

$\mathrm{PhD}$, Associate Professor, Dean Department of Construction Operations**

E-mail: nahornyimykola@gmail.com

*Department of Chemical Technology of Ceramics and Glass Ukrainian State University of Chemical Technology

Gagarina ave., 8, Dnipro, Ukraine, 49005

** Sumy National Agrarian University

Herasyma Kondratieva str., 160, Sumy, Ukraine, 40021

Copyright (C) 2019, O. Khomenko, B. Datsenko, N. Sribniak, O. Zaichuk, M. Nahornyi This is an open access article under the CC BY license (http://creativecommons.org/licenses/by/4.0)

\section{Introduction}

In modern construction, decorative materials with high operation and aesthetic requirements are in great demand. These materials include engobe ceramic brick, which is becoming increasingly popular, because the variety of these coatings allows the implementation of any design solutions.

Ceramic bricks that imitate manual molding and have the "antiquity" effect, gradient transitions of colors and other decorative effects enjoy special attention. However, it is necessary to take into account a number of questions in order to engobe ceramic bricks and obtain high quality products. In particular, it is relevant to develop coatings for single annealing of bricks, coordinate the shrinkage processes of the engobe and ceramic base and ensure high physical and mechanical indicators of construction articles.

Wienerberger (Poland), Randers Tegl (Denmark), Recke Brickerei (Russia) and others are among the well-known manufacturers of engobe ceramic brick. But there is no information about the composition of engobe coatings, the technology of their application and annealing modes. There are also no scientific explanations of physical and chemical processes of sintering of building ceramics. That is why the study of technological and physical-chemical fundamentals of the production of engobed ceramic brick is of scientific and practical interest. 


\section{Literature review and problem statement}

Engobes are widely used in the ceramic industry in the production of both ceramic tiles [1-3], and tableware [4]. But the technology of manufacturing such products differs from the production of ceramic bricks [5], mainly, by the composition of the mass and fine processing of raw materials. This, in turn, causes fundamentally different mechanisms of the interaction of the coating and the ceramic basis. That is why such engobes are not used for the decoration of coarsegrained ceramic bricks.

When it comes to the engobes for ceramic bricks, there is relatively little information in scientific literature. In particular, the information about the possibility of creating volumetric or gradient decorative effects with a single application of the coating on a ceramic brick was not found.

Paper [6] presents the results of the development of engobe coatings for ceramic facing brick. It is shown, that red clay is used to obtain the basis for manufacturing the engobe, and the necessary colors are provided by the introduction of pigments. But the mechanisms of the interaction of the coating and ceramic basis were not explored, which does not explain the ways of correcting their shrinkage processes. In addition, the use of pigments makes the cost of production much higher.

Article [7] contains the results of the development of the technology of manufacturing colored engobed brick. The compositions of the ceramic mass and the coating, to which clay, by-products of mining and concentrating and metallurgical plants, limestone and cullet were introduced, were developed. The physical and chemical processes of coloring of engobe coating in the brown range of colors were analyzed. But the decorative effect of such engobe is only enhancement of the natural color of the basic clay, besides, it has a monotonous nature.

There is some information [8] on the use of metallurgical dust, which adds color to coatings. The main mineralogical phase of dust is hematite $\alpha-\mathrm{Fe}_{2} \mathrm{O}_{3}$, so the use of this product makes it possible to replace the synthetic and natural iron oxides, which are the part of expensive ceramic pigments, and to dispose of multi-ton wastes. But such engobe is limited in color diversity.

In papers [9-11], the influence of the compositions of engobes and some technological factors on the properties of coatings were investigated. Thus, the influence of the content of refractory clay, kaolin and bentonite in the charge on the rheological properties of slips and the strength of adhesion of engobes with ceramic base were studied in article [9]. It was found that the differences in the properties of the studied engobes relate to different crystalline lattice of clay minerals. The results on the improvement of decorative and operating properties of engobe ceramic coatings for the construction ceramics by introducing wollastonite to the composition of the engobe charge were obtained in [10]. The rate of sintering and the mechanism of the mass transfer in ceramic engobes were also studied in [11]. The dominant mass transfer mechanisms are grains regrouping, dissolving-deposition and the reaction on the grains' boundaries. The problem of harmonization of the shrinkage processes in the ceramic base and the coating is raised and partially solved in research [12]. It was determined that the introduction to the engobe composition of the vitreous activator, received by the sol-gel method, allows the intensification of sintering of the engobe layer and improvement of its interac- tion with the ceramic base during annealing. But the mechanism of the interaction of the coating and the semi-finished product at all stages of the technological process was not outlined in detail, neither were the possibilities of creating decorative effects of coatings.

Thus, the production of engobes for ceramic bricks is currently outlined in scientific literature in the aspect of the preparation of white base of a certain composition, which is applied to the ceramic semi-finished product or on the annealed product. Decorative variety of engobe is provided only by a change in the color of the base by introducing expensive pigments. Little attention is paid to the study of shrinkage processes, which occupy a significant place in the production of construction ceramics [13], which increases the risk of defects in products at all stages of the technological process.

The lack of information about the development of the technology for obtaining engobed ceramic bricks with volumetric decorative effects, including the "antiquity" effect, is related to the fact that the demand for such products has appeared relatively recently. The use of the traditional technology of production of engobed bricks by means of preparing the clay base of the engobe with pigment coloration is not appropriate as it makes the cost of products significantly higher. That is why there is a need for the development of the composition, manufacturing technology and application of decorative engobe coating with volumetric texture. In this case, special attention should be paid to solving the problem of coordination of shrinkage processes of engobe coating and the ceramic base at all stages of the production cycle, which is inseparably connected with a change in the engobe composition and technological parameters of production.

\section{The aim and objectives of the study}

The aim of the research was to develop the technology for obtaining engobed construction ceramics with the volumetric "antiquity" texture and high indicators of operational properties.

To accomplish the aim, the following tasks have been set:

- to explore the basic properties of the ceramic semi-finished product and annealed shard;

- to establish the main technological parameters for preparation of the engobe slip, to study its rheological properties and physical and ceramic characteristics of the material after sintering;

- to establish the most expedient method for application of the engobe coating on the ceramic base;

- to establish the physical and chemical bases for the formation of decorative "antiquity" effect of the engobe coating.

\section{Materials and methods to study the technological foundations for obtaining engobed construction articles with the "antiquity" effect}

The engobe, which included light-burning clay of the Druzhkivka deposit (Donetsk oblast, Ukraine), the cullet of the colorless glass containers, manganese ore of Nikopol manganese ore basin (Dnipropetrovsk oblast, Ukraine), was taken as basic in the research. To achieve volumetric texture of the coating, the microspheres of fly ash of heat power plant 
of TOV SPE "Spetsmaterials" (Boryspil, Ukraine) were introduced to the engobe composition.

Semi-finished sun-dried clay brick, obtained by the method of extrusion from the mixture of plastic clays, was taken as the ceramic base.

The rheological properties of engobe coatings and physical-ceramic indicators of the samples were assessed by the standard methods [14]. The fineness of engobe slip grinding was determined by the amount of residue on sieve No. 0063. The indicator of slip fluidity, which is the time of flowing of $100 \mathrm{ml}$ of suspension through a hole of $4 \mathrm{~mm}$ in size, was mean sured with the help of the Ford bowl. The shrinkage indicators were determined by a change in the size of samples - semi-finished products before and after drying and annealing. Water absorption of sintered materials was assessed by the amount of absorbed water in the open pores of the sample after saturation in vacuum and with the help of hydrostatic weighing. The indicator of engobe hardness by the Mohs scale was determined by scratching the surface by the minerals with appropriate hardness.

Adhesion of coatings to the ceramic base was measured by the method of lattice cut.

The microstructure of the coating was studied in the reflected light with the help of optical microscope MBS-10 (Lytkarinsk plant of optical glass, Russia).

The nature of thermal transformations of ceramic masses was determined by means of differential-thermal analysis using the derivatograph by the system F. Paulik, J. Paulik, L. Erdey Q-1000 (made by "MOM", Hungary).

The temperature coefficient of linear expansion of materials was determined with the help of the vertical quartz dilatometer DKV-5 (GIS, Russia).

\section{The results of development of the technology for obtaining engobed construction articles with the "antiquity" effect}

5.1. Studying basic properties of ceramic semi-finm ished product and the annealed shard

The most common way of forming ceramic brick is extrusion of plastic masses [15]. In the process of drying, such products have significant shrinkage, which should be taken into account when harmonizing the coating and ceramic base. The most important indicators of the properties for ceramic masses are air and fire shrinkage, as well as the degree of sintering, which is evaluated by water absorption. The value of the basic indicators of the studied mass and the samples burnt from it at $1,070{ }^{\circ} \mathrm{C}$ are given in Table 1 .

\section{Table 1}

Properties of the studied ceramic mass and ceramic samples

\begin{tabular}{|c|c|}
\hline Indicator & Value \\
\hline Normal operating moisture content of the mass, $\%$ & 21 \\
\hline Air shrinkage, $\%$ & 5.3 \\
\hline Fire shrinkage (annealing t $1,070{ }^{\circ} \mathrm{C}$ ), $\%$ & 0.9 \\
\hline Water absorption (annealing at $1,070{ }^{\circ} \mathrm{C}$ ), $\%$ & 9.4 \\
\hline Temperature coefficient of linear expansion, $1 /{ }^{\circ} \mathrm{C}$ & $5.5 \cdot 10^{-6}$ \\
\hline
\end{tabular}

Thus, the studied ceramic mass has air shrinkage (5.3\%) that is typical of plastic clay compositions and much lower indicator of fire shrinkage $(0.9 \%)$. The latter is associated with increased sand content of natural raw materials, which, if there is sufficient capability of clay particles, on the whole, positively influences the formation of products during annealing and prevents deformation.

Differential-thermal analysis of the ceramic mass (Fig. 1) allows establishing that the processes of dehydration and decomposition of gas-containing components end at $780-800{ }^{\circ} \mathrm{C}$. Thus, the first endothermic effect with the maximum of $120^{\circ} \mathrm{C}$ is associated with the removal of residual moisture from the ceramic semi-finished product. The second endothermic effect with the maximum at $530{ }^{\circ} \mathrm{C}$ is associated with kaolinite dehydration, and the third at $780{ }^{\circ} \mathrm{C}$ accompanies the processes of decomposition of carbonate and mica impurities. The exoeffect at $910^{\circ} \mathrm{C}$ indicates the crystallization of mullite from the products of decomposition of clay minerals. That is, when choosing the engobe composition, it must be taken into account that up to the temperature of $800{ }^{\circ} \mathrm{C}$, the engobe coating does not have to be intensively compacted and, moreover, sintered, and has to let the products of ceramic mass decomposition pass freely.

Analysis of the microstructure of the semi-finished product showed (Fig. 2) that despite the ceramic mass belonging to the class of coarse-grained, the semi-finished product forms a rather dense structure in the process of thermal treatment.

The degree of sintering (vitrification) of the clay mass is high, the stony particles are well-jointed by the glass phase (Fig. 2, a). It should be noted that the average size of pores reaches $0.2-0.4 \mathrm{~mm}$, large pores (more than $0.5 \mathrm{~mm}$ ) in the structure of the shard are found in single cases, which is achieved by high-quality vacuuming of the mass and the absence of impurities in the raw materials of burning impurities.

The smooth surface of the sample (Fig. 2, b) is formed during the extrusion, and after annealing is highly homogeneous, without microcracks and other defects. There is a glass phase, which during fixing the coating on a ceramic product will contribute to the formation of a strong transition layer between ceramics and the engobe.

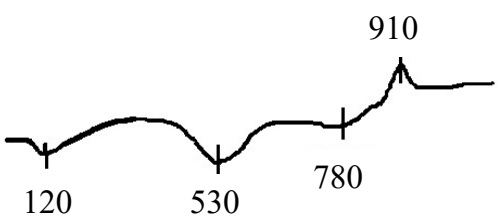

Fig. 1. Thermogram of the studied ceramic mass
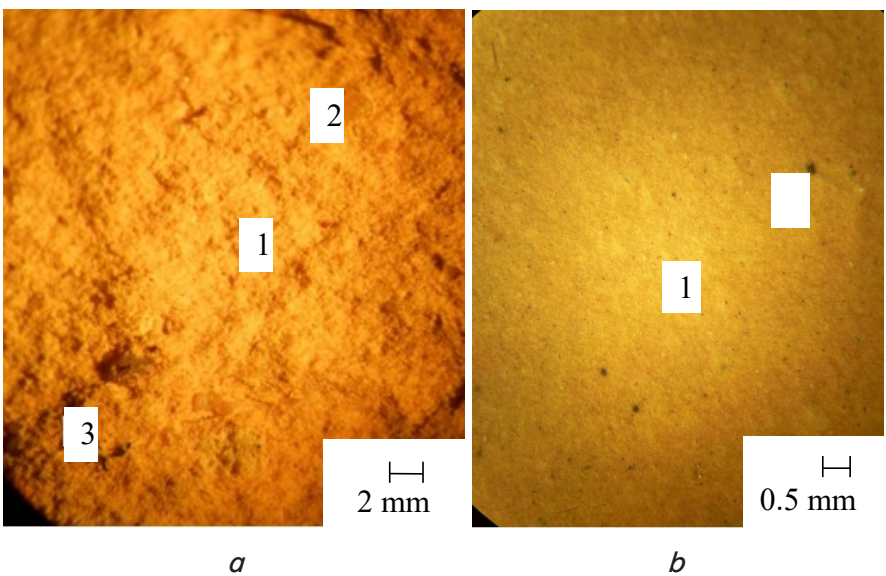

Fig. 2. The microstructure of the ceramic sample, reflected light: $a$ - fracture, $b$ - surface; 1 - basic glass-mullite mass, 2 - inclusion of quartz, 3 - pore, 4 - inclusion of iron-containing minerals 
Thus, the study of the properties of the basic ceramic mass showed that the air and fire shrinkage are $5.3 \%$ and $0.9 \%$, respectively Determining these indicators, as well as the nature of thermal transformations at heating and peculiarity of the formation of the microstructure of a ceramic shard during annealing at $1,070{ }^{\circ} \mathrm{C}$, gave grounds to design the composition of the engobe charge.

5. 2. Establishment of the main technological parameters for the preparation of engobe slip, to study its rheological properties and physical-ceramic characteristics of the material after sintering

The engobe components (Table 2) were chosen taking into consideration of their role at sintering and the interaction with the ceramic shard.

Table 2

Studied composition of engobe coatings, \% by weight

\begin{tabular}{|c|c|c|c|c|c|c|c|c|c|}
\hline \multirow{2}{*}{ Components } & \multicolumn{3}{|c|}{ Numbers of composition } & \multicolumn{5}{c|}{$\begin{array}{c}\text { Numbers of compo- } \\
\text { sitions }\end{array}$} \\
\cline { 2 - 10 } & 0 & 1 & 2 & 3 & 0 & 1 & 2 & 3 \\
\cline { 2 - 9 } & \multicolumn{3}{|c|}{$\begin{array}{c}\text { at introduction of ash } \\
\text { above } 100 \% \text { by weight of } \\
\text { the basic engobe of mass }\end{array}$} & \multicolumn{5}{|c|}{$\begin{array}{l}\text { converted to } 100 \% \text { by } \\
\text { weight of engobe mass }\end{array}$} \\
\hline $\begin{array}{c}\text { Light-burning } \\
\text { clay }\end{array}$ & 10.0 & 10.0 & 10.0 & 10.0 & 10.0 & 9.7 & 9.4 & 9.2 \\
\hline $\begin{array}{c}\text { Cullet of } \\
\text { transparent } \\
\text { glass }\end{array}$ & 25.0 & 25.0 & 25.0 & 25.0 & 25.0 & 24.3 & 23.6 & 22.9 \\
\hline $\begin{array}{c}\text { Manganese } \\
\text { ore }\end{array}$ & 65.0 & 65.0 & 65.0 & 65.0 & 65.0 & 63.1 & 61.3 & 59.6 \\
\hline $\begin{array}{c}\text { Microgranules } \\
\text { of TPP fly ash }\end{array}$ & - & 3.0 & 6.0 & 9.0 & - & 2.9 & 5.7 & 8.3 \\
\hline $\begin{array}{c}\Sigma \text { of compo- } \\
\text { nents }\end{array}$ & 100 & 103 & 106 & 109 & 100 & 100 & 100 & 100 \\
\hline
\end{tabular}

Light-burning clay is intended to provide the rheological properties of the engobe slip at the stage of its preparation, adhesion grip to the ceramic base when applying and forming a dense structure during annealing. But given the high shrinkage of light burning clay, its contents in the engobe composition was accepted in the amount of $10 \%$ by weight.

Feldspar materials [16] are commonly used to intensify sintering of ceramic materials, but at temperatures up to $1,100{ }^{\circ} \mathrm{C}$ feldspars are ineffective, that is why an artificial sintering additive - cullet of transparent glass (package) was introduced to the engobe compositions. Cullet initiates the active liquid phase sintering of the coating and strengthens adhesion to the ceramic base.

Manganese ore additionally promotes sintering of the engobe layer and is the main source of the saturated darkbrown color of the coating with the lilac tint.

The rheological properties of the basic engobe slip (without ash) and sintered coating are given in Table 3.

To determine the sintering ability of the engobe coating, the experimental samples-plates were prepared from the slip of the basic composition, which were annealed after drying at the temperature of $1,070{ }^{\circ} \mathrm{C}$. The indicator of water absorption of the annealed material was $5.4 \%$, and the air and fire shrinkage was $1.8 \%$ and $2.1 \%$, respectively. Comparing the data from Tables 1,3, it can be concluded that the degree of sintering of ceramic mass and engobe coating is significantly different (water absorption of engobe and that of the brick sample was $5.2 \%$ and $9.4 \%$, respectively). It is necessary to pay special attention to the fact that the shrinkage processes of the two materials differ significantly (Fig. 3).

Table 3

Rheological properties of the basic engobe slip and sintered coating

\begin{tabular}{|c|c|c|c|}
\hline Indicator & Value & Indicator & Value \\
\hline \multicolumn{2}{|l|}{ Slip } & \multicolumn{2}{|l|}{ Engobe } \\
\hline $\begin{array}{l}\text { Residue on sieve } \\
\text { No. } 0063, \%\end{array}$ & $<1.0$ & Air shrinkage, \% & 1.8 \\
\hline Fluidity, s & 18 & $\begin{array}{l}\text { Water absorption (an- } \\
\left.\text { nealing at } 1,070{ }^{\circ} \mathrm{C}\right), \%\end{array}$ & 5.2 \\
\hline Moisture content, \% & 45 & $\begin{array}{l}\text { Fire shrinkage (anneal- } \\
\left.\text { ing at } 1,070^{\circ} \mathrm{C}\right), \%\end{array}$ & 2.1 \\
\hline Thickening coefficient & 2.2 & Hardness by Mohs scale & $\sim 5$ \\
\hline
\end{tabular}

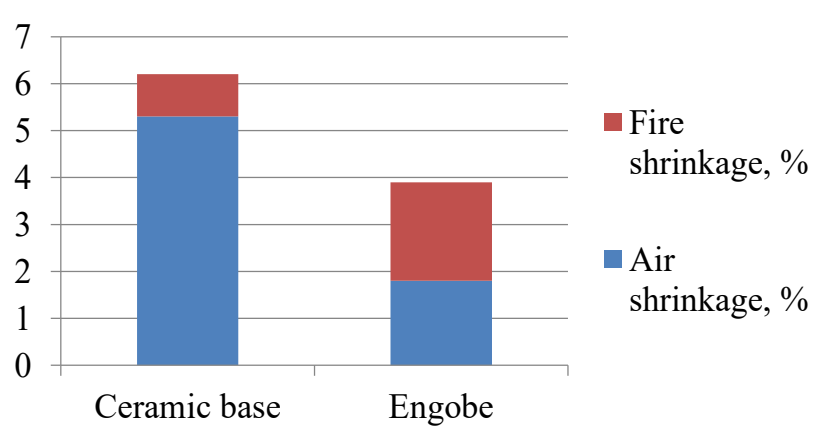

Fig. 3. The ratio of shrinkage of ceramic base and engobe

Ceramic mass consisting of a mixture of plastic clays undergoes removal of physically bound water during drying, dehydration and decomposition of other gas-containing components during annealing (Fig. 1). Downsizing of the sample begins intensively during drying of the semi-finished product and flows with considerably less intensity to the temperature of $780-800{ }^{\circ} \mathrm{C}$.

The engobe mass contains only $10 \%$ by weight of the clay component, so its air shrinkage is not so intensive. When heated, the engobe slip also undergoes physical and chemical transformations (Fig. 4). When heated in the area of low temperatures (within $150{ }^{\circ} \mathrm{C}$ ), hygroscopic moisture is lost, which is accompanied by not clearly pronounced endo-effect. The first significant endo-effect with the maximum at $550{ }^{\circ} \mathrm{C}$ is associated with the removal of chemically bound water from the semi-refractory kaolinite clay, which exists in the composition of the engobe slip. As the main component of the engobe is manganese ore, the curve of thermal analysis has appropriate endothermic effects [17]. At $620^{\circ} \mathrm{C}$, a strong pyrolusite effect of formation of $\beta-\mathrm{Mn}_{2} \mathrm{O}_{3}$ with $\beta-\mathrm{MnO}_{2}$ is observed. At $830{ }^{\circ} \mathrm{C}$, there is decomposition of polypermanganates and carbonate-containing minerals, and at $980{ }^{\circ} \mathrm{C}, \beta-\mathrm{Mn}_{3} \mathrm{O}_{4}$ is formed. But these thermal transformations flow mainly at the time when the ceramic shard has already a dense structure, so these physical and chemical processes will not cause destruction or occurrence of other defects in the ceramic product.

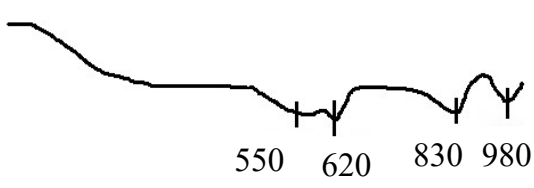

Fig. 4. Thermogram of engobe coating 
Fly ash is widely used in the production of construction brick [18] as a component of the ceramic mass, which improves the thermal insulation capacity. Ash is introduced to the composition of the studied engobes in order to obtain an additional volumetric decorative effect.

The microgranules of the TPP fly ash are the loose powder, which is formed in the composition of fly ash in electrofilters or cyclones at combustion of coal at thermal power plants. The main component of ash (65\%) is a vitreous aluminosilicate phase in the form of spherical particles of dimensions of up to 200-250 microns. Dispersion of ash is characterized by specific surface of $2,400 \mathrm{~cm}^{2} / \mathrm{g}$ and average bulk density of $790 \mathrm{~kg} / \mathrm{m}^{3}$.

The introduction of ash into the composition of liquid engobe slip is limited to its high hydrophobic ability, so the ash content was varied in the narrow limits of 3-9\% by weight of the basic engobe. Production of experimental engobe (No. 1-3, Table 2) was carried out by wet grinding of components in a ball mill at the moisture content of the suspension of $45 \%$ to the residue on sieve No. 0063 of no more than $1 \%$. The ash microgranules were introduced to the composition of engobe slip after grinding by careful stirring for 20 minutes before obtaining a smooth suspension.

It should be noted that ash microgranules have a hydrophobic ability and are practically not distributed throughout the volume of the engobe slip, they are constantly found near the surface. In this regard, the slip has to be constantly stirred.

Thus, the main technological parameters of the engobe slips are the following: moisture content $45 \%$, residue on the sieve No. 0063 - no more than $1 \%$. The rheological indicator of fluidity in this case equals to $18 \mathrm{~s}$. The feature of the preparation of the experimental engobes is that the introduction of fly ash to engobe slips is carried out after grinding the basic engobe composition. Otherwise, ash will not create the volumetric decorative effect.

5. 3. Establishment of the most expedient method for application of engobe coating on the ceramic base

Given the considerable difference of air shrinkage of the engobe and ceramic charge, the coating was applied both on the freshly formed semi-finished product and on the dried one, as the mechanism of shrinkage of the product in each of these variants is different. The engobe slip was applied by pouring on the face surface of the ceramic samples, which after drying up to the moisture content of not more than $3 \%$ were annealed at $1,070{ }^{\circ} \mathrm{C}$ with keeping for 1 hour.

Results from the visual analysis of engobe coatings are given in Table 4.

When applied to freshly formed ceramic semi-finished product, the coatings had good adhesion to the ceramic base. But after drying we observed numerous microcracks on the surface of the samples even of the basic engobe (without ash).

The mechanism of the occurrence of microcracks is as follows (Fig. 5, a). The ceramic mass has much larger air shrinkage [19] than the engobe coating, so the semi-finished product is intensively reduced in size. The engobe with good adhesion with the raw semi-finished product begins to shrink in size along with the sample. However, at some point, the engobe particles no longer have enough surface to shrink, the internal stresses between the particles increase and, seeking a "release", break the integrity of the engobe layer.

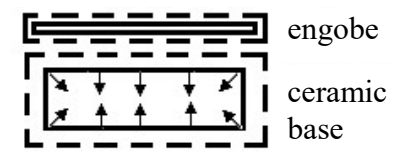

$a$

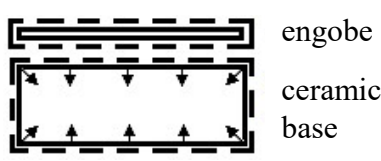

$b$
Fig. 5. Schematic representation of shrinkage processes of engobed ceramic samples when applying the engobe: $a-$ on a raw semi-finished product, $b$ - on a dried semi-finished product

Table 4

\begin{tabular}{|c|c|c|c|c|c|c|c|c|}
\hline \multirow{3}{*}{ Indicator } & \multicolumn{4}{|c|}{$\begin{array}{c}\text { Application of engobe on raw semi-fin- } \\
\text { ished product }\end{array}$} & \multicolumn{4}{|c|}{$\begin{array}{l}\text { Application of engobe on dry } \\
\text { semi-finished product }\end{array}$} \\
\hline & \multicolumn{4}{|c|}{ Number of engobe composition } & \multicolumn{4}{|c|}{ Number of engobe composition } \\
\hline & 0 & 1 & 2 & 3 & 0 & 1 & 2 & 3 \\
\hline $\begin{array}{l}\text { Surface qual- } \\
\text { ity (visual } \\
\text { assessment) } \\
\text { before an- } \\
\text { nealing }\end{array}$ & \multicolumn{2}{|c|}{$\begin{array}{l}\text { There are microc- } \\
\text { racks on the surfaces } \\
\text { and engobes were } \\
\text { partially chipped } \\
\text { at the edges of the } \\
\text { samples }\end{array}$} & \multicolumn{2}{|c|}{$\begin{array}{l}\text { In addition to } \\
\text { microcracks, there } \\
\text { are bare surfaces } \\
\text { because of chip- } \\
\text { ping of fragments } \\
\text { of coatings }\end{array}$} & \multicolumn{3}{|c|}{$\begin{array}{c}\text { Coatings do not } \\
\text { have defects and do } \\
\text { not peel off from the } \\
\text { ceramic base }\end{array}$} & $\begin{array}{c}\text { Bare } \\
\text { sections } \\
\text { of surfaces } \\
\text { are ob- } \\
\text { served }\end{array}$ \\
\hline $\begin{array}{c}\text { Surface } \\
\text { quality after } \\
\text { annealing }\end{array}$ & \multicolumn{4}{|c|}{$\begin{array}{l}\text { In places where the coating was not } \\
\text { chipped after drying, there was a strong } \\
\text { adhesion of the coating and ceramic } \\
\text { base during annealing }\end{array}$} & \multicolumn{4}{|c|}{$\begin{array}{l}\text { Coatings are tightly fused with } \\
\text { the ceramic base }\end{array}$} \\
\hline $\begin{array}{l}\text { Existence of } \\
\text { volumetric } \\
\text { relief }\end{array}$ & - & ++ & ++ & +++ & - & ++ & ++ & +++ \\
\hline $\begin{array}{l}\text { Existence of } \\
\text { gradient tran- } \\
\text { sition }\end{array}$ & - & - & + & ++ & - & - & + & ++ \\
\hline Color & $\begin{array}{c}\text { Dark } \\
\text { brown }\end{array}$ & $\begin{array}{l}\text { Dark bro } \\
\text { existence }\end{array}$ & $\begin{array}{l}\text { vn witl } \\
\text { flight }\end{array}$ & $\begin{array}{l}\text { ac tint, } \\
\text { iability" }\end{array}$ & $\begin{array}{c}\text { Dark } \\
\text { brown }\end{array}$ & $\begin{array}{l}\text { Dark } \\
\text { tint, }\end{array}$ & $\begin{array}{l}\text { row } \\
\text { cistel } \\
\text { arial }\end{array}$ & $\begin{array}{l}\text { n with lilac } \\
\text { nce of light } \\
\text { bility" }\end{array}$ \\
\hline
\end{tabular}

When applying the engobe on a dry ceramic sample, the adhesion grip of the coating and the ceramic base are smaller, even at wetting the surface of the ceramic material. This is due to the fact that the difference between the moisture content of the engobe slip and the dry ceramic semi-finished product is too big. However, the difference in shrinkage is much smaller (Fig. 5, $b$ ), that is why during drying and annealing, arising micro stresses do not result in the damage of the samples.

Thus, at a significant difference in the shrinkage of the engobe and the ceramic base, it is necessary to apply the engobe on the dried semi-finished product. This will make it possible to decrease the probability of microcracks on the surface of the engobe or its chipping.

5. 4. Establishment of physical and chemical foundations of the formation of decorative "antiquity" effect of the engobe coating

The peculiarity of the studied engobes is to create a volumetric decorative "antiquity" effect. This effect is formed (Fig. 6) after annealing, due to the flow of complex physical 
or refractory clay or kaolin as the main clay component. But the aim of this work was to obtain the engobe coating of thick dark brown color with a decorative effect. That is why it would be inappropriate to use as the main component semi-refractory clay, the deposits of which in the country are rapidly exhausted, and it would be even more irrational to use costly pigments for coatings coloration.

That is why the unconventional raw material - manganese ore - was chosen as the basic component for obtaining the engobe. In terms of physical and chemical transformations in the treatment of manganese ore (Fig. 4), the overwhelming number of shrinkage processes occurs in the high temperature areas, which is an advantage, since it will allow fuller formation of the structure of the ceramic shard. While the ceramic shard is freed from the products of dehydration and decarbonization of clay raw materials up to the temperatures of $780-800{ }^{\circ} \mathrm{C}$, the engobe layer does not get thickened and lets them pass freely. Then, the engobe layer is finally formed during sintering in the interval of $830-1,000{ }^{\circ} \mathrm{C}$.

Thus, the developed engobe includes the light burning clay as the suspending additive, and the cullet of transparent containers as an effective melt. Manganese ore gives the engobe base thick dark brown color. However, to achieve the decorative effect of surface melting and the formation of the gradient of color, emphasizing the artificial "antiquity" of construction articles, another rather atypical for this purpose raw material - the TPP fly ash - was used in the study.

The studies revealed that the most complicated thing is to harmonize the shrinkage processes of the ceramic base and the engobe coating at the stages of drying and annealing. The ceramic semi-finished product, made by the extrusion method from plastic masses, has greater air shrinkage than the engobe composition. This is due to the fact that the composition of the latter, in addition to the clay material, includes leaning components, so the convergence of the particles of the engobe layer is less intense. The above indicates the need for application of the engobe layer not on the freshly formed, but rather on the dried semi-finished product.

The mechanisms of the formation of the coating on the ceramic semi-finished product were established and explained and the method for the application of the engobe slip was substantiated. The high adhesion ability of the engobe slip is ensured at the thinness of grinding the charge components of not more than $1 \%$ by the residue on the No. 0063 sieve and humidity of $45 \%$. However, due to high hydrophobic ability of ash microspheres, the engobe slip needs constant stirring.

Thus, to achieve a decorative "antiquity" effect of engobe coatings, it was found that it is expedient to introduce to the composition of the engobe slip the manganese ore in the amount of $65 \%$ by weight and the microgranules of the TPP fly ash from 3 to $6 \%$ by weight over $100 \%$ by weight of the dry matter. The combination of these components provides a volumetric effect of "variability" and dark brown-lilac color and significantly changes the mechanism and kinetics of the processes of sintering of engobe coatings, intensifying them.

It is necessary to consider the advantages of the research on establishment of the mechanism of interaction of the engobe coating, made based of semi-refractory clay raw materials, with a ceramic shard, based on plastic clay.

The merits of these studies include the development of the engobe coating that is fundamentally new for the domestic construction industry. Previously, to achieve such a decorative effect, it was necessary to use the expensive frit, special powder, to create special conditions for annealing (for example in a ring kiln), etc. The use of the TPP fly ash as a decorating component of the engobe is very original and rather technological. In addition, there are prospects of combining the gradient effect, created by the TPP fly ash, with other colors of engobe coatings that enjoy demand of consumers.

The proposed coating is intended for single annealing of construction articles, which makes it possible to produce them by the energy-efficient technology.

The disadvantages of the conducted study are that the influence of the granulometric and charge composition of the engobes' base on their physical and mechanical properties were not sufficiently studied.

The results of these studies are useful and can be applied in the production of construction materials, in particular, engobed ceramic bricks. In the application of the compositions of the developed engobe coatings and meeting the established conditions of the technological process, it is possible to obtain attractive new high quality products. This, in turn, will make it possible to expand the range of construction ceramics and increase its competitiveness. This paper can be subsequently used to expand the color range of engobe coatings.

\section{Conclusions}

1. The study of the properties of the basic ceramic mass showed that the normal working moisture content is $21 \%$ and the air and fire shrinkage are equal to $5.3 \%$ and $0.9 \%$, respectively. At the temperature of $1,070{ }^{\circ} \mathrm{C}$, the ceramic sample has water absorption $9.4 \%$, does not contain any signs of incomplete annealing or deformation. That is why these technological parameters became the basis in designing the composition of the engobe blend.

2 . The composition of the engobe coatings includes light burning clay and cullet to provide the adhesion ability of the coating and intensification of sintering, respectively, and manganese ore and the TPP fly ash as decorating components. The quantitative ratio is the following, $\%$ by weight: light burning clay -9.4 , cullet of transparent glass - 23.6, manganese ore - 61.3, microgranules of TPP fly ash -5.7 . The basic technological parameters of engobe slips make up: moisture content $-45 \%$, residue on sieve No. 0063 - no more than $1 \%$. The rheological indicator of fluidity is equal to $18 \mathrm{~s}$. The peculiarity of the preparation of the studied engobes is the fact that the introduction of fly ash to the slips is carried out after grinding the basic engobe composition.

3. It was established that the quality of the engobe coating is greatly influenced by the method of application - on a damp or on a dry semi-finished product. At a significant difference between the shrinkages of the engobe and the ceramic base, it is necessary to apply the engobe slip on a dried semi-finished product. This will make it possible to decrease the probability of occurrence of microcracks on the surface of the engobe or its chipping.

4. The physical and chemical grounds of the formation of the decorative "antiquity" effect of the engobe coating were identified. The dark brown-lilac color after annealing the engobed products at the temperature of not more than $1,070{ }^{\circ} \mathrm{C}$ is formed due to the chemical transformations of pyrolusite $\mathrm{MnO}_{2}$, manganese spilt $\mathrm{MnCO}_{3}$ other minerals of manganese ore that flow during annealing the engobed ceramics. The volumetric decorative effect with a light "variability" is provided by the microgranules of TPP fly ash. 


\section{References}

1. Nestertsov, A. I. (2004). Underglaze engobe for ceramic facing tiles. Glass and Ceramics, 61 (11-12), 413-414. doi: https://doi.org/ 10.1007/s10717-005-0015-3

2. Becker, E., Jiusti, J., Minatto, F. D., Delavi, D. G. G., Montedo, O. R. K., Noni Jr., A. de. (2017). Use of mechanically-activated kaolin to replace ball clay in engobe for a ceramic tile. Cerâmica, 63(367), 295-302. doi: https://doi.org/10.1590/036669132017633672077

3. Nandi, V. S., Raupp-Pereira, F., Montedo, O. R. K., Oliveira, A. P. N. (2015). The use of ceramic sludge and recycled glass to obtain engobes for manufacturing ceramic tiles. Journal of Cleaner Production, 86, 461-470. doi: https://doi.org/10.1016/ j.jclepro.2014.08.091

4. Luangnaem, C., Sathonsaowaphak, A., Kamon-In, O., Pimraksa, K. (2014). Development of Engobe Samples for Dan Kwian Ceramic Body. Key Engineering Materials, 608, 325-330. doi: https://doi.org/10.4028/www.scientific.net/kem.608.325

5. Khomenko, O., Sribniak, N., Dushyn, V., Shushkevych, V. (2018). Analysis of the interaction between properties and microstructure of construction ceramics. Eastern-European Journal of Enterprise Technologies, 4 (6 (94)), 16-25. doi: https://doi.org/10.15587/ 1729-4061.2018.140571

6. Yatsenko, N. D., Rat'kova, É. O. (2009). Engobes for ceramic brick. Glass and Ceramics, 66 (3-4), 93-94. doi: https://doi. org/10.1007/s10717-009-9144-4

7. Zorigt, S., Jadamba, Ts., Tsevel, S. (2012). Synthesis and structural studies of face engobe layer's mass. 2012 7th International Forum on Strategic Technology (IFOST). doi: https://doi.org/10.1109/ifost.2012.6357603

8. Ovčačíková, H., Vlček, J., Klárová, M., Topinková, M. (2017). Metallurgy dusts as a pigment for glazes and engobes. Ceramics International, 43 (10), 7789-7796. doi: https://doi.org/10.1016/j.ceramint.2017.03.091

9. Moreno, A., Bou, E., Navarro, M. C., García, J. (2000). Influencia de los materiales plásticos sobre las características de los engobes. I Tipo de material arcilloso. Boletín de La Sociedad Española de Cerámica y Vidrio, 39 (5), 617-621. doi: https://doi.org/10.3989/ cyv.2000.v39.i5.778

10. Vakalova, T. V., Revva, I. B., Pogrebenkov, V. M. (2007). Protective-decorative coatings for construction ceramics based on West Siberian natural raw material. Glass and Ceramics, 64 (1-2), 27-30. doi: https://doi.org/10.1007/s10717-007-0007-6

11. Dal Bó, M., Boschi, A. O., Hotza, D. (2013). Cinética de sinterización y transporte de masa en engobes cerámicos. Boletín de La Sociedad Española de Cerámica y Vidrio, 52 (5), 237-241. doi: https://doi.org/10.3989/cyv.292013

12. Khomenko, O., Alekseev, E. (2018). Development of a sol-gel technique for obtaining sintering activators for engobe coatings. Eastern-European Journal of Enterprise Technologies, 6 (6 (96)), 43-51. doi: https://doi.org/10.15587/1729-4061.2018.150606

13. Moroz, B. I., Datsenko, B. M., Kolesnikova, I. V. (1984). Linear expansion of argillaceous mineral compositions. Glass and Ceramics, 41 (11), 505-508. doi: https://doi.org/10.1007/bf00704679

14. Guzman, I. Ya. (Ed.) (2005). Praktikum po tehnologii keramiki. Moscow, 334.

15. Schilling, C. H. (2001). Plastic Forming. Encyclopedia of Materials: Science and Technology, 7088-7092. doi: https://doi.org/ 10.1016/b0-08-043152-6/01256-0

16. Fedorenko, E. Y., Ryshchenko, M. I., Daineko, E. B., Chirkina, M. A. (2013). Energy-saving technology for household porcelain. Glass and Ceramics, 70 (5-6), 219-222. doi: https://doi.org/10.1007/s10717-013-9547-0

17. Mattisson, T., Sundqvist, S., Moldenhauer, P., Leion, H., Lyngfelt, A. (2019). Influence of heat treatment on manganese ores as oxygen carriers. International Journal of Greenhouse Gas Control, 87, 238-245. doi: https://doi.org/10.1016/j.ijggc.2019.05.027

18. Esmeray, E., Atıs, M. (2019). Utilization of sewage sludge, oven slag and fly ash in clay brick production. Construction and Building Materials, 194, 110-121. doi: https://doi.org/10.1016/j.conbuildmat.2018.10.231

19. Khomenko, E. S., Purdik, A. V. (2017). Particulars of Microstructure Formation in Clinker Ceramic. Glass and Ceramics, 74 (1-2), 48-51. doi: https://doi.org/10.1007/s10717-017-9926-z

20. Chatterjee, S., Jung, I.-H. (2014). Critical evaluation and thermodynamic modeling of the Al-Mn-O (Al2O3-MnO-Mn2O3) system. Journal of the European Ceramic Society, 34 (6), 1611-1621. doi: https://doi.org/10.1016/j.jeurceramsoc.2013.12.017 